\title{
Surface Characterization of Cottonseed Meal Products by SEM, SEM- EDS, XRD and XPS Analysis
}

\author{
Zhongqi He${ }^{1}$, Huai N. Cheng ${ }^{1}$, O. Modesto Olanya ${ }^{2}$, Joseph Uknalis ${ }^{2}$, \\ Xiaodong Zhang ${ }^{3}$, Brent D. Koplitz ${ }^{3} \&$ Jibao He $^{4}$ \\ ${ }^{1}$ Southern Regional Research Center, USDA Agricultural Research Service, New Orleans, LA 70124, USA \\ ${ }^{2}$ USDA-ARS, Eastern Regional Research Center, 600 East Mermaid Lane, Wyndmoor, PA 19038, USA \\ ${ }^{3}$ Department of Chemistry, Tulane University, New Orleans, LA 70118, USA \\ ${ }^{4}$ Coordinated Instrument Facility, Tulane University, New Orleans, LA 70118, USA \\ Correspondence: Zhongqi He, USDA-ARS, 1100 Robert E. Lee Blvd., New Orleans, LA 70124, USA. Tel: 1-504- \\ 286-4516. E-mail: Zhongqi.He@ars.usda.gov
}

Received: December 19, 2017

Accepted: January 1, 2018

Online Published: January 1, 2018

doi:10.5539/jmsr.v7n1p28

URL: https://doi.org/10.5539/jmsr.v7n1p28

\begin{abstract}
The utilization of cottonseed meal products as valuable industrial materials needs to be exploited. We have recently produced water-washed cottonseed meal, total cottonseed protein, sequentially extracted water- and alkali-soluble proteins, and two residues after the total and sequential protein extractions at a pilot scale. In this work, the surface characteristics of the six cottonseed meal products were examined by scanning electron microscopy (SEM), scanning electron microscopy- energy dispersive spectrometer (SEM-EDS), X-ray diffraction (XRD), and X-ray photoelectron spectroscopy (XPS). The results showed that the surface properties of the six products differed from those of a commercial soy protein flour examined comparatively in this work. The compact morphology and relative-high $\mathrm{N}$ composition were observed in all three protein products, with greater similarity between the total protein and alkali-soluble protein. The surfaces of the two residue products were more porous with polysaccharide features. Washed cottonseed meal possessed the surface features similar to those of the residues. In the meantime, the $\mathrm{N}$-associated functional groups were under-represented in the surfaces of all samples, compared to their bulk composition. Information derived from this work increased the understanding of the surface functional properties of cottonseed meal products, which would benefit their practical utilization.
\end{abstract}

Keywords: Cottonseed meal; cottonseed protein; oilseed, soy protein; surface properties

\section{Introduction}

Cotton is one of the most important non-food crops in the world. From this interesting and renewable resource, it is possible to obtain a large variety of products that can be utilized in many disparate fields (Proto et al., 2000; Liu et al., 2015). Similarly, cotton is America's number one value-added crop. Much of the cotton land area in the US is located in the southern and southeastern region (e. g., Georgia, Alabama, Mississippi, and Texas) (Bellaloui et al., 2015; Tazisong et al., 2013; Tewolde et al., 2015). Cotton crop is mainly harvested for the cotton bolls (He et al., 2016d; He et al., 2017b; Liu et al., 2016; Windeatt et al., 2014). Cotton fiber, cottonseed oil and defatted cottonseed meal are the three major products of cotton bolls. Cotton fiber is used for textiles and clothing and cottonseed oil is used in margarine and soap (Proto et al., 2000). However, the utilization of defatted cottonseed meal as a valuable industrial stock feed and a fertilizer needs to be further exploited (Grevellec et al., 2001; Grewal and Khare, 2017; He and Cheng, 2017; Swiatkiewicz et al., 2016). Recent work (Cheng et al., 2013; 2016; He et al., 2014a; 2014b; He and Chiozza, 2017) has shown that two cottonseed meal products, washed cottonseed meal (WCSM) and cottonseed protein isolate (CSPI), could be used as "green" wood adhesives. He et al. (2016c) further scaled up the production of WCSM and co-products from laboratory 10-g levels to pilot production levels of 10$\mathrm{lb}(4.54 \mathrm{~kg})$ starting material. Generation of a sizable volume of cottonseed meal-based products set the foundation for further promoting the enhanced utilization of cottonseed meal-based products as biobased raw materials.

Proteins are built up with amino acids via peptide bond linkage into complex three-dimensional shapes (Adhikari et al., 2017). Thus, the functional properties of proteins are dependant not only on the chemical composition, but also on multiple conformational characteristics (Jia et al., 2017; Qi et al., 2017; Zhu et al., 2016). In particular, the 
surface properties of protein are related with its numerous functional properties in practical utilization, such as wetting, dispersion, oxidative stability, flowability and rehydration properties (Gaiani et al., 2011; Nawaz et al., 2016; Zhao et al., 2011). Zhao et al. (2015) reported that soy protein powder made by reverse micelle extraction showed more -sheet and pore structures than that extracted by aqueous buffer extraction. The reverse micelles extraction was further shown to affect the $\mathrm{C}, \mathrm{O}$ and $\mathrm{N}$ components on the surface of walnut protein powder (Liu et al., 2014). Kelly et al. (2015) found that increasing protein concentration of spray-dried milk protein concentrates resulted in altered surface composition and increased monolayer moisture value and glass-rubber transition temperature values. By measuring surface chemical composition, Saad et al. (2011) reported that the surface composition of native wheat flour possessed an over-representation of protein (54\%) and lipids (44\%) and an under-representation of starch (2\%) compared to the bulk composition. Similarly, Nawaz et al. (2016) found higher contents of proteins and lipids on the surface of rice kernels and flours than in the bulk composition.

Previous characterization of cottonseed meal products were mainly on the chemical composition (Berardi and Cherry, 1979; He et al., 2015; Zhang et al., 2009), protein structure (He et al., 2013a; 2014c; King, 1980), and physicochemical properties (Grevellec et al., 2001; He et al., 2016b; Tunc and Duman, 2007; Zhou et al., 2015). Unlike several agricultural products noted above, the surface characteristics of cottonseed meal products have not been examined so far. Therefore, the objective of the present study was to characterize the surface properties of six cottonseed meal products using scanning electron microscopy (SEM), scanning electron microscopy- energy dispersive spectrometer (SEM-EDS), X-ray diffraction (XRD), and X-ray photoelectron spectroscopy (XPS). For comparison, a commercially available soy protein flour was also examined in the same way as relevant information is available for soy protein powders (Chen et al., 2013; Zhao et al., 2015; 2011). Characterization of surface properties would enhance their potential utilization for various agro-based and industrial purposes.s.

\section{Method}

\subsection{Materials}

Mill-scale produced defatted cottonseed meal was provided by Cotton, Inc. (Cary, NC, USA) and was used as the starting material of the pilot-scale production of washed cottonseed meal and co-products as reported in $\mathrm{He}$ et al. (2013a; 2016c). The six products used in this work were one-step alkali-extracted cottonseed protein isolate (CSPI) and the extraction residual (CSRi), water-soluble protein fraction (CSPw) and alkali-soluble protein fraction (CSPa) and the residual (CSIR) from sequential extraction of cottonseed meal by deionized water and $0.015 \mathrm{M} \mathrm{NaOH}$, and washed cottonseed meal (WCSM). These products were freeze-dried and ground to pass a $0.5-\mathrm{mm}$ screen. Soy protein isolate flour (SPI) was purchased from an on-line vendor (www.bulkfoods.com). It was used without further treatment. All samples were kept in a desiccator at room temperature $\left(22^{\circ} \mathrm{C}\right)$ until use.

\subsection{Scanning electron microscopy (SEM) and scanning electron microscopy-energy dispersive spectroscopy (SEM-EDS}

Samples for SEM analysis were mounted on aluminum stubs with double carbon tape and sputter gold coated for 1 minute (EMS 150R ES, EM Sciences, Hatfield, PA). Samples were then viewed with a FEI Quanta $200 \mathrm{~F}$ Scanning Electron Microscope (Hillsboro, OR, USA) with an accelerating voltage of $10 \mathrm{kV}$ in high vacuum mode. The images of samples were then scanned at 500x and 1,000x (magnifications) for comparison of treatment effects.

For EDS processing, samples were mounted on aluminum stubs with double sided carbon tape. Elemental analysis was done with an Oxford Xmax ${ }^{\mathrm{n}} 80 \mathrm{~mm}^{2}$ Detector (Oxford Instruments, Tubney Woods Abingdon, Oxfordshire OX13 5QX, United Kingdom). Spectra acquisition and interpretation was performed with AZtec software version 3.1 (Oxford Instruments). Spectra were acquired at $30 \mathrm{kV}$ and spot size of 5 for each sample..

\section{$2.3 \mathrm{X}$-ray diffraction $(X R D)$ analysis}

Samples were analyzed at room temperature by an XRD diffractometer (Scintag, XDS 2000) using a Cu-K $\alpha$ Xray source with a wavelength (k) of $1.54059 \AA$. The generator was operated at $43 \mathrm{kV}$ and $38 \mathrm{~mA}$. The divergence and receiving slits were 1.0 and $0.3 \mathrm{~mm}$, respectively. Diffractograms were taken from $3^{\circ}$ to $80^{\circ}(2 \theta)$ at a rate of $1.02 \theta \mathrm{min}^{-1}$ and with a step size of $0.03(2 \theta)$. The run time of each sample was about 45 min with counting time per step $=3.0 \mathrm{sec}$ (calculated).

\section{$2.4 X$-ray photoelectron spectroscopy (XPS)}

XPS measurements were conducted on a VG Scientific MKII system (West Sussex, UK) using an Al K $\alpha$ anode as excitation source $(\mathrm{h} v=1486.6 \mathrm{eV})$ at $15 \mathrm{kV} 40 \mathrm{~mA}$. The pressure in the chamber during analysis was $<5 \times 10^{-8}$ mbar. The sample powders were loosely packed in stainless steel sample holders, and the surface was leveled. The whole surface (about half inch diameter) of each sample was radiated with X-ray. Scans were carried out with a 
pass energy of $20 \mathrm{eV}$ with the energy step of $0.2 \mathrm{eV}$ and the step time of 10 seconds for survey scans or 60 seconds for select region scans. The binding energy of the spectrometer has been calibrated by referencing to the $\mathrm{C} 1 \mathrm{~s}$ peak at $284.8 \mathrm{eV}$. It is a common practice to use the carbon $\mathrm{C} 1 \mathrm{~s}$ peak at $284.8 \mathrm{eV}$ as reference for charge compensation as the $\mathrm{C} 1 \mathrm{~s}$ component is bound exclusively to carbon or hydrogen (Ahimou et al., 2007; Liu et al., 2014; Olivares et al., 2006; Yang et al., 2016). Peak fitting was performed with custom VBA program in Microsoft Excel using Voigt profiles together with a Shirley background function

\section{Results and Discussion}

\subsection{SEM and SEM-EDS morphological characteristics}

Morphological characteristics of the seven samples are shown in Figure 1. The surface of CSIR and CSRi samples was irregularly wrinkled with light spongy porous structures. This feature was apparently attributed to predominant insoluble polysaccharide components (fiber, cellulose, hemicellulose, lignin etc.) left in the two residual samples after protein extraction and removal of other soluble components (He et al., 2015). The microstructure of WCSM sample looked like the surface features of the residual samples, but with more flat areas. The particles of the three cottonseed protein products (i.e., CSPI, CSP and CSPw) showed crystalline features tight surfaces and sharp angles There were no obvious open pores observed. The morphologies of the cottonseed protein products, and afterextraction residues were similar to those of separated wheat protein and arabinoxylans (hemicelluloses), respectively (Saad et al., 2011). On the other hand, the microstrcutures of these cottonseed proteins were not as smooth as that of the commercial soy protein powder used in this work for comparison purpose. Their particle size distribution was also not as homogenous as the soy protein powder. Indeed, the morphology of the soy protein powders was not like those reported in Zhao et al. (2015), rather than spray-dried milk protein concentrates with attached spherical shape protein on the surface (Kelly et al., 2015). The difference in these observations could be attributed to the fact that both protein concentrations and treatment procedures could have affected the morphology of protein products. Kelly et al. (2015) reported that the low protein powders of spray-dried milk products had a wrinkled surface and, as the protein content increased, the powder surfaces became smoother with smooth dimples evident as observed in our soy protein sample.
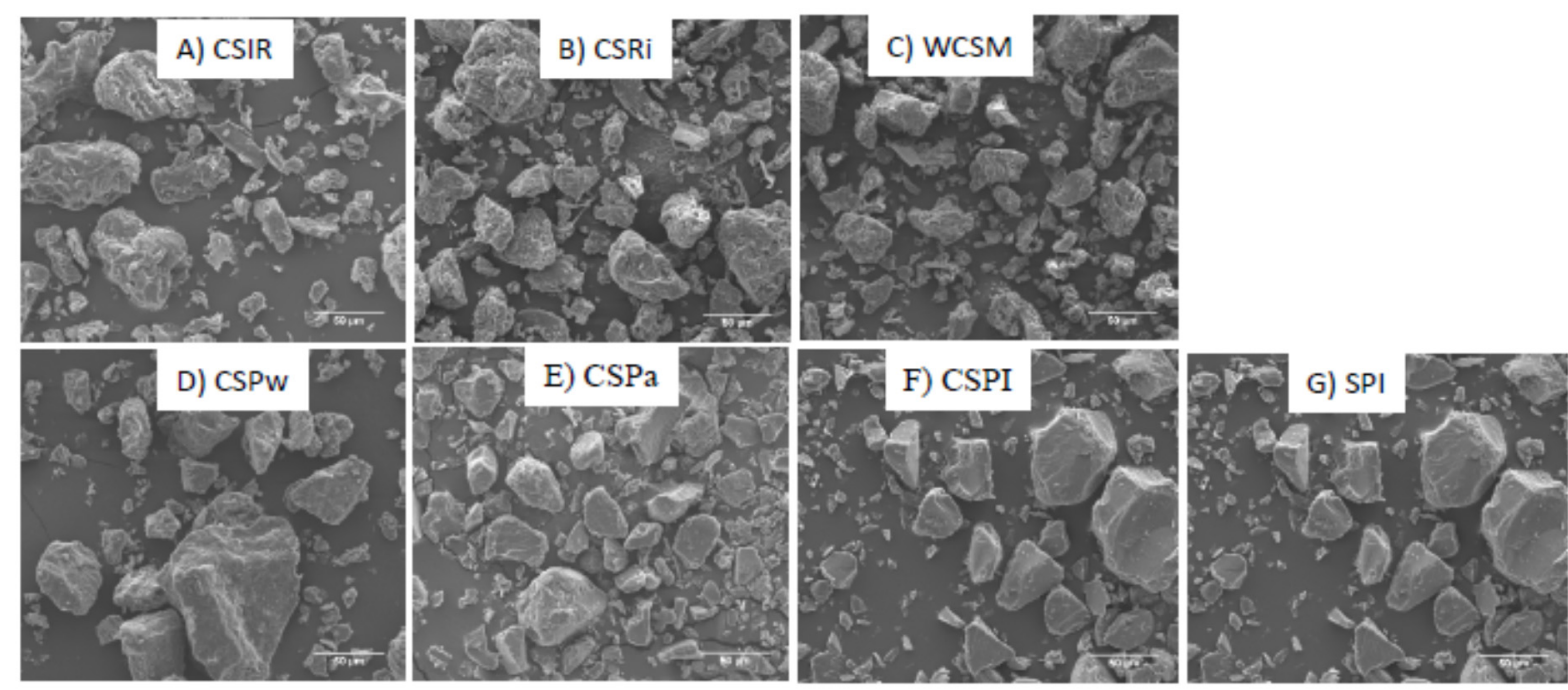

Figure 1. SEM images of the cottonseed meal products and soy protein samples. CSPI, one-step alkali-extracted cottonseed protein isolate (CSPI); CSPw and CSPa, sequentially extracted water-soluble protein fraction and alkali-soluble protein fraction, respectively; CSIR, the residual fraction after the two-step sequential extraction by water and alkali; CSRi, the residual fraction after one-step alkali extraction; WCSM, water-washed cottonseed meal; and SPI, soy protein isolate 


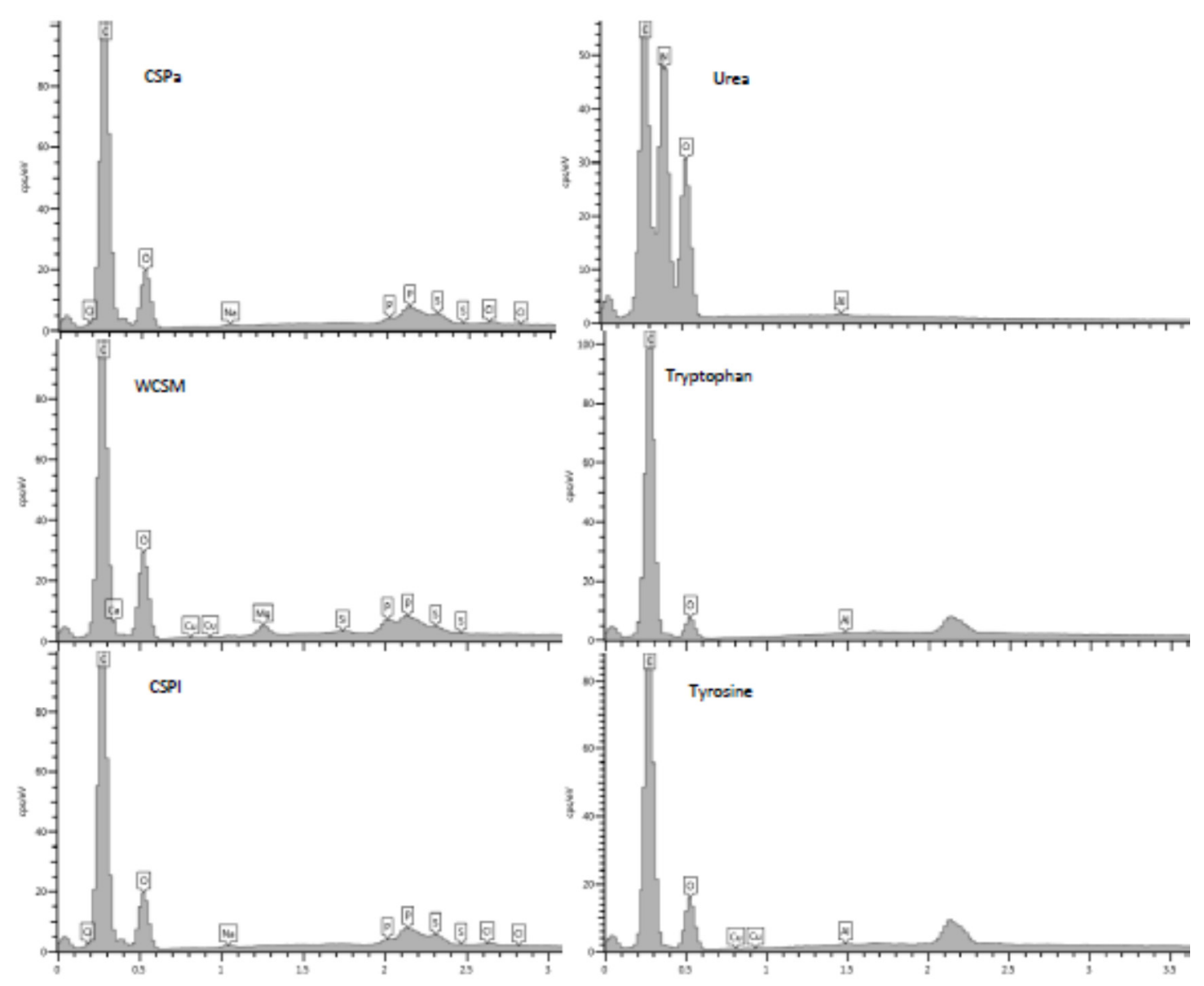

Figure 2. EDS spectrograms of alkali-soluble cottonseed protein (CSPa), water washed cottonseed meal (WCSM), total cottonseed protein isolate (CSPI), and control samples (urea, L-tryptophan, and L-tyrosine)

\subsection{EDS analysis (Surface composition)}

The EDS spectrograms of the seven samples looked similar. The representative spectrograms of CSPa,WCSM, and CSPI samples are presented in Figure 2. Strong peaks of $\mathrm{C}$ and $\mathrm{O}$ were detected as they are the major elements in organic materials. Several trace mineral elements (i.e. $\mathrm{Ca}, \mathrm{Cu}, \mathrm{Na}, \mathrm{Mg}, \mathrm{K}$, and P) were also detected in the surface of these cottonseed meal products and soy protein powders. The percentage order of these minerals in the cottonseed meal products was similar to that in the bulk samples determined previously with ICP spectrometer after acid digestion (He et al., 2016c). However, the values of the percentages determined by SEM-EDS were lower by $30-50 \%$ (Table 1 ). The $\mathrm{Cl}$ ion found in all four protein samples (i. e., CSPw, CSPa, CSPI, and SPI) might be the residues of $\mathrm{HCl}$ during $\mathrm{pH}$ neutralization for protein precipitation. In the seven samples, SPI possessed the highest $\mathrm{C}$ and lowest $\mathrm{O}$ contents. The contents of the two elements in CSPa and CSPI were similar, consistent with the similar molecular structure and protein patterns of the alkaline-soluble cottonseed protein fraction and the total protein isolate reported previously (He et al., 2013a; 2014c). Compared to other three protein samples, CSPw possessed a lower $\mathrm{C}$ and higher $\mathrm{O}$ contents, which could be attributed to protein was accounted only about $65 \%$ of the mass in the pilot-produced CSPw fraction (He et al., 2016c). The two residues after protein extractions (i.e., CSIR and CSRi) were at the similar levels of $\mathrm{C}$ and $\mathrm{O}$, suggesting no difference in the chemical composition of the residues after the protein extracted either by one-step or two-step procedures. The increase in $\mathrm{O}$ content, compared to the protein samples, would be attributed to the O-rich polysaccharide components in the residues. It was observed that WCSM which still contained protein components possessed even higher O content than the two residues samples, suggesting that some O-rich components could be more oriented at the surface of WCSM particles. Indeed, the high $\mathrm{P}, \mathrm{K}$ and $\mathrm{Mg}$ in WCSM was evidence of the presence of O-rich $\mathrm{K}$ and $\mathrm{Mg}$ phytate (inositol) (He et al., 2006; 2013b). These phytate compounds might have interacted with protein components in WCSM richened in the surface region (Han, 1988; Luna-Valdez et al., 2017). 
Table 1. Elemental composition ( $\%$ atom) of the cottonseed meal products and soy protein samples by SEM-EDS analysis.

\begin{tabular}{llllllll}
\hline Element & $\mathrm{CSPw}^{\mathrm{c}}$ & $\mathrm{CSPa}$ & CSPI & SPI & WCSM & CSIR & CSRi \\
\hline $\mathrm{C}$ & 68.2 & 70.7 & 71 & 72.3 & 62.6 & 65.8 & 65.2 \\
$\mathrm{O}$ & 30.4 & 28.8 & 28.4 & 26.9 & 35.6 & 32.7 & 33.7 \\
$\mathrm{~K}$ & 0.4 & $0.0^{\mathrm{a}}$ & 0.1 & 0.1 & 0.7 & 0.4 & 0.4 \\
$\mathrm{Mg}$ & 0.1 & - & - & - & 0.4 & 0.4 & 0.3 \\
$\mathrm{Na}$ & $-{ }^{\mathrm{b}}$ & 0.2 & - & 0.5 & - & 0.2 & 0.2 \\
$\mathrm{Cu}$ & - & - & 0.2 & - & 0.2 & - & 0.2 \\
$\mathrm{Ca}$ & - & - & - & 0.1 & 0.1 & 0.1 & 0.1 \\
$\mathrm{~S}$ & 0.2 & 0.2 & 0.1 & 0 & 0.1 & 0.0 & - \\
$\mathrm{P}$ & 0.4 & 0.0 & 0.0 & 0 & 0.3 & 0.3 & - \\
$\mathrm{Cl}$ & 0.2 & 0.1 & 0.1 & 0.1 & - & - & - \\
$\mathrm{Si}$ & 0.1 & - & - & - & 0.0 & - & - \\
\hline
\end{tabular}

a. Detected, but with $<0.1 \%$ of composition.

b. Not detected.

It was noteworthy that $\mathrm{N}$, a representative protein component, did not appear in the EDS spectrograms of these protein samples, which was consistent with the earlier obversation with WCSM samples with different particle sizes (He et al., 2017a). Therefore, we also ran the SEM-EDS analysis of simple organic $\mathrm{N}$ compound urea $\left(\mathrm{H}_{2} \mathrm{NCONH}_{2}\right)$ and two amino acids (i. e. two-N L-tryptaphan and one-NL- tyrosine) (Figure 2). The N peak of urea was obvious between the $\mathrm{C}$ and $\mathrm{O}$ peak, and accounted for about $47 \%$ of the sample mass. But no $\mathrm{N}$ peak was observed in the spectrograms of the two amino acids. These observations indicated the capability of the EDS in detecting $\mathrm{N}$ atom; and the failure in $\mathrm{N}$ detection in our SEM-EDS was more due to the complicated sample matrix as the matrix exerts significant effects on the detection of N by SEM-EDS (Gazulla et al., 2013). Hou et al. (2017) examined protein (bovine serum albumin, BSA) fouling control during membrane distillation process. Their SEMEDS spectrograms of the fouling scattered on membrane surface with BSA in the absence and presence of calcium ion showed the $\mathrm{N}$ peak clearly between the $\mathrm{C}$ and $\mathrm{O}$ peaks. The SEM-EDS analysis revealed that the deposit on the membrane surface was the complex formed by BSA and calcium chloride. However, Muruganantham et al. (2009) did not report the detection of $\mathrm{N}$ in the leaf, stem and root samples of two medicinal plants, Eclipta alba Hassk and Eclipta prostrata Linnm using SEM-EDS. Luna-Valdez et al. (2017) were puzzled when no N was detected in aqueous extracts of wheat bran (AEWB) nanoparticles prepared with $\mathrm{CaCl}_{2}$ treatments even though the protein content in these AEWB samples was high. They hypothesized that the protein molecules were in the center of the particles, covered by a layer of polysaccharides and/or other components, so that the X-rays were not able to reach the amino acid residues and excite the electrons of N. While the protein purity of CSPa, CSPI, and SPI were quite high (about $100 \%$ ), the lack of the N peak could not be attributed to the masking effect of nonprotein components only. Perhaps, non-N atoms or groups of atoms shielded $\mathrm{N}$ from the surface of the protein structures. Further rigorous studies are needed to validate this assumption.

\subsection{XRD Examination}

The XRD patterns of the seven samples are presented in Figure 3 and the quantitative data are presented in Table 2. There were two obvious peaks at $2 \theta$ of about 9.4 and $20^{\circ}$ in the XRD pattern of the four protein samples. These features are typical for soy protein powders, reflecting the $\alpha$-helix and $\beta$-sheet structures of protein molecules, respectively (Chen et al., 2013; Luo et al., 2016; Zhao et al., 2015). The intensity of both peaks was in the order $\mathrm{CSPa}<\mathrm{CSPI}<\mathrm{CSPa}$, indicating that the two-step fractionation unequally delivered less $\alpha$-helix and $\beta$-sheet protein components into water-soluble fraction than alkali-soluble fraction. In addition, the ratios of the intensity of Peak 1 and 2 were 0.35 for CSPw and 0.49 for CSPa, respectively. Therefore, the water-soluble cottonseed protein fraction $(\mathrm{CSP})$ contained less $\alpha$-helix structure than the alkali-soluble fraction (CSPa). The intensity of the two peaks and their ratio (0.41) of the total cottonseed protein (CSPI) were between the values of the two fractions also confirmed the unequal distribution of the a-helix and b-sheet structures into the two fractions. The difference in the secondary structure was not observed in the bulk CSPw and CSPa samples based on FTIR analysis (He et al., 2013a). However, the difference in the a-helix and b-sheet structures was also observed in the 7S and 11S globulins from soybean proteins based on XRD analysis (Chen et al., 2013). On the other hand, it is noteworthy that the quantitative data of soy protein sample (SPI) we tested were closer to CSPa, rather than total cottonseed protein (CSPI). 


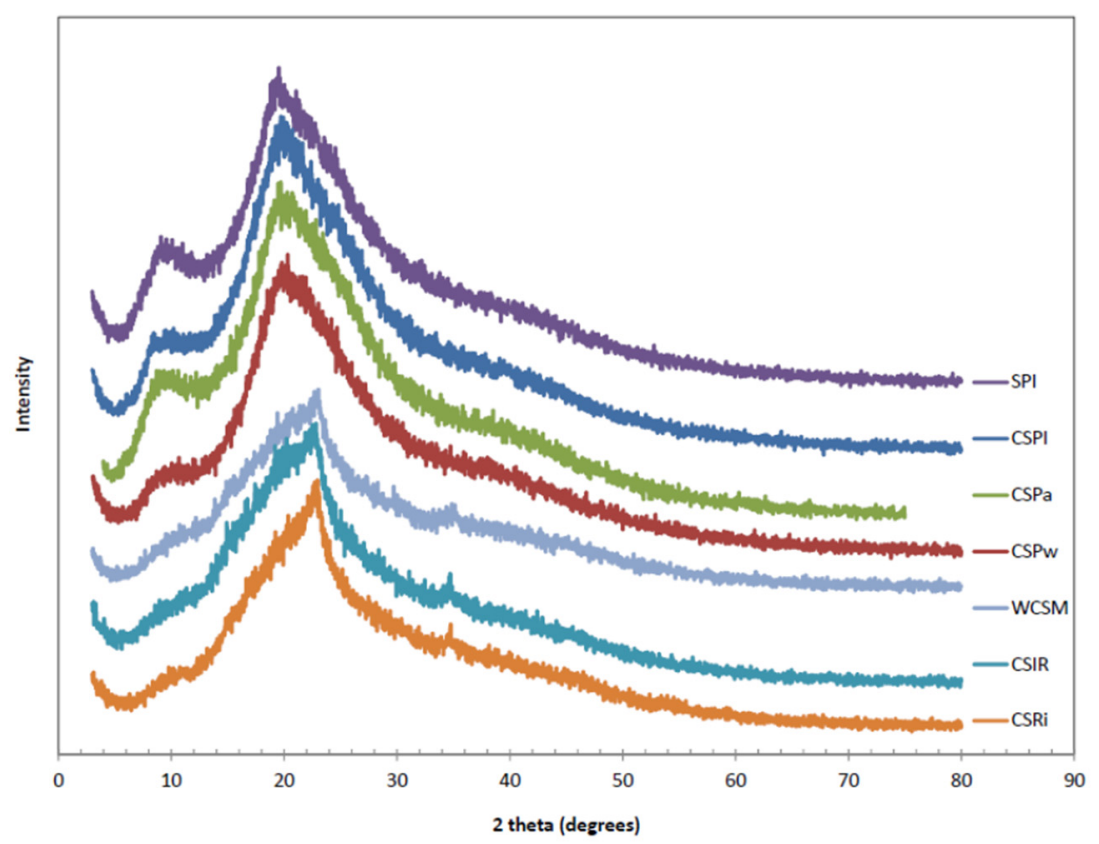

Figure 3. X-ray diffraction patterns of the cottonseed meal products and soy protein samples. Refer to the legend of Fig. 1 for sample information

Table 2. XRD parameters of the cottonseed meal products and soy protein samples

\begin{tabular}{llllllllll}
\hline & Peak 1 & \multicolumn{3}{c}{ Peak 2 } & \multicolumn{5}{c}{ Peak 3 } \\
\hline Sample $^{\text {a }}$ & $2 \theta\left(^{\circ}\right)$ & $\begin{array}{l}\text { Relative } \\
\text { intensity }\end{array}$ & $\begin{array}{l}\text { Distance } \\
(\AA)\end{array}$ & $2 \theta\left(^{\circ}\right)$ & $\begin{array}{l}\text { Relative } \\
\text { intensity }\end{array}$ & Distance $(\AA)$ & $2 \theta\left(^{\circ}\right)$ & $\begin{array}{l}\text { Relative } \\
\text { intensity }\end{array}$ & $\begin{array}{l}\text { Distance } \\
(\AA)\end{array}$ \\
\hline CSPw & 9.42 & 499 & 9.38 & 20.31 & 1418 & 4.37 & $-{ }^{\mathrm{b}}$ & - & - \\
CSPa & 9.36 & 765 & 9.44 & 19.50 & 1547 & 4.55 & - & - & - \\
CSPI & 9.51 & 642 & 9.29 & 19.71 & 1567 & 4.50 & - & - & - \\
SPI & 9.33 & 708 & 9.47 & 19.38 & 1437 & 4.58 & - & - & - \\
WCSM & 10.08 & 403 & 8.77 & 23.04 & 983 & 3.86 & 34.77 & 434 & 2.58 \\
CSIR & 9.51 & 462 & 9.29 & 22.83 & 1236 & 3.98 & 34.71 & 584 & 2.58 \\
CSRi & 9.78 & 377 & 9.04 & 22.95 & 1189 & 3.92 & 34.74 & 555 & 2.58 \\
\hline
\end{tabular}

a. $\mathrm{CSPw}$ and CSPa, sequentially extracted water-soluble protein fraction and alkali-soluble protein fraction, respectively; CSPI, one-step alkali-extracted cottonseed protein isolate; CSIR, the residual fraction after the twostep sequential extraction by water and alkali; CSRi, the residual fraction after one-step alkali extraction; WCSM, water-washed cottonseed meal; and SPI, soy protein isolate.

b. No peak detected.

The XRD patterns of WCSM were similar to those of CSIR and CSRI, but differed from the other four protein samples (Figure 3). Compared to those of protein samples, the minor peak became a weak shoulder. The major peak shifted to $2 \theta$ at about $23^{\circ}$. Similarly, an additional minor peak appeared at $2 \theta$ near $35^{\circ}$ (Table 2). These features were more similar to those of cellulose and other lignocellulosic materials (Tserki et al., 2005; Zhang et al., 2014). Tserki et al. (2005) reported that the XRD patterns of spruce flour and oil husk flour exhibited two well defined peaks at $2 \theta$ of $22.0^{\circ}$ (major) and $34.4^{\circ}$ (minor), and a broad shoulder at $2 \theta$ near $16.0^{\circ}$. These features were attributed to cellulose crystallographic form I. Furthermore, weaker shoulder at $2 \theta$ near $16.0^{\circ}$ would suggest that cellulose I lattice was severely distorted with a low order (i.e., high amounts of amorphous materials such as lignin, hemicelluloses, and amorphous cellulose) (Zhang et al., 2014). In our samples, the shoulder at $16^{\circ}$ was not observed. Thus, we assumed the major structures of WCSM, CSIR and CSRi shown by XRD were the mixtures of cellulose I and amorphous cellulose. Intensity data (Table 2) suggested that there was no difference in the cellulose structure content between the two residual samples CSIR and CSRi, but less content in WCSM sample. This observation seemed reasonable as WCSM also contained protein ingredients. 


\subsection{XPS analysis}

The XPS survey spectra of the seven samples are presented in Figure 4. The three predominant features were the $\mathrm{C} 1 \mathrm{~s}, \mathrm{O} 1 \mathrm{~s}$ and N1s peaks. Elemental analysis of the surface of theses samples was based on binding energies of $\mathrm{C} 1 \mathrm{~s}, \mathrm{~N} 1 \mathrm{~s}$ and $\mathrm{O} 1 \mathrm{~s}$, which were in the ranges of 281-293, 397-408, and 528-533 eV, respectively (Kelly et al., 2015). For comparison, available bulk composition of $\mathrm{C}$ and $\mathrm{N}$ of several samples is also presented (Table 3 ). The data of C and O detected by XPS (Table 3) were not exactly the same as those of SEM-EDS (Table 1). The different values were apparently due to the fact that the total elemental composition detected by the two methods was not the same. The different surface layers detectable might also play a role in the difference such as XPS determined the elemental composition of the outmost surface layer ( $6 \mathrm{~nm}$ depth) of the protein samples (Zhao et al., 2015).

XPS analysis showed that the $\mathrm{C}$ level was relatively higher on the surface than in the bulk, which was also consistent with the trend of the SEM-EDS data (Table 1). On the other hand, the $\mathrm{N}$ level was markedly lower on the surface than in the bulk only in CSPa, CSPI and SPI samples ( $>4 \%)$. The difference in the N content in other four samples was $<1 \%$ between the surface and bulk samples. Based on XPS analysis, Kelly et al. (2015) observed that protein and fat contents were higher, but lactose and mineral contents were lower, in surface than in the bulk of their milk protein concentrate powders. Our data are not consistent with their observation. It is obvious that the $\mathrm{C}, \mathrm{N}, \mathrm{O}$ data in Table 3 could be separated into two groups. The first group could be cottonseed protein products (CSPw, CSPa, and CSPI). They possessed lower $\mathrm{C}$ and $\mathrm{O}$ contents, but higher $\mathrm{N}$ content than the second group of WCSM, CSIR and CSRi. The data indicated that, similar to their bulk composition, the surface of cottonseed protein products was protein rich, and the surface of the meal and residues after protein isolation were rich in carbohydrate. In this work, XPS analysis revealed that the surface of the soy protein samples SPI has the highest $\mathrm{C}$ content, but the lowest $\mathrm{N}$ and $\mathrm{O}$ contents among the seven samples. These data seemed to suggest that the $\mathrm{C}$ side groups, rather than the amino groups were more tending or aligned to the surface in the soy protein powder.

High resolution XPS spectra of C, N, and O peaks of representative CSPI are in Figure 5. Our data did not allow us to discern among $\mathrm{N}$ species or $\mathrm{O}$ species, with only one peak each having the best fitting. On the other hand, deconvulation identified four $\mathrm{C}$ species with $\mathrm{C}(1)$ as the primary $\mathrm{C}, \mathrm{C}(3)$ as the moderate $\mathrm{C}$, and $\mathrm{C}(2)$ or $\mathrm{C}(4)$ as minor $\mathrm{C}$ species (Table 4). In addition, there was an unresolved $\mathrm{X}$ peak about $4 \mathrm{eV}$ lower than $\mathrm{C} 1$ s peak. This peak could be an artifact, or an unidentified C species. Currently, most studies (Ahimou et al., 2007; Liu et al., 2014; Yang et al., 2016) assigned the major C(1) peak as the lowest C peak with the binding energy at $284.8 \mathrm{eV}$. However, literature is available for $\mathrm{C}$ species with lower binding energy values. Zhao et al. $(2011,2015)$ set the value of $\mathrm{C}(1)$ peak at 283.6-283.8 eV, leaving the difference between $\mathrm{C}(2)$ and $\mathrm{C}(1)$ peaks at $3.1 \mathrm{eV}$, rather than about $1.5 \mathrm{ev}$ as in Table 4. Olivare et al. (2006) observed a C-C aromatic bond related peak at the binding energy of $284.3 \mathrm{eV}$, lower than the major peak $(284.9 \mathrm{eV})$ of the $\mathrm{C}-\mathrm{C}$ aliphatic bonds. However, the unidentified $\mathrm{X}$ peak in Figure 5 was more apparent and shifted lower than the binding energy shifting in the studies of Zhao et al. $(2011 ; 2015)$ and Olivare et al. (2006). Whereas the X peak was presents in all seven samples, more rigorous studies are needed to clarify its identity.

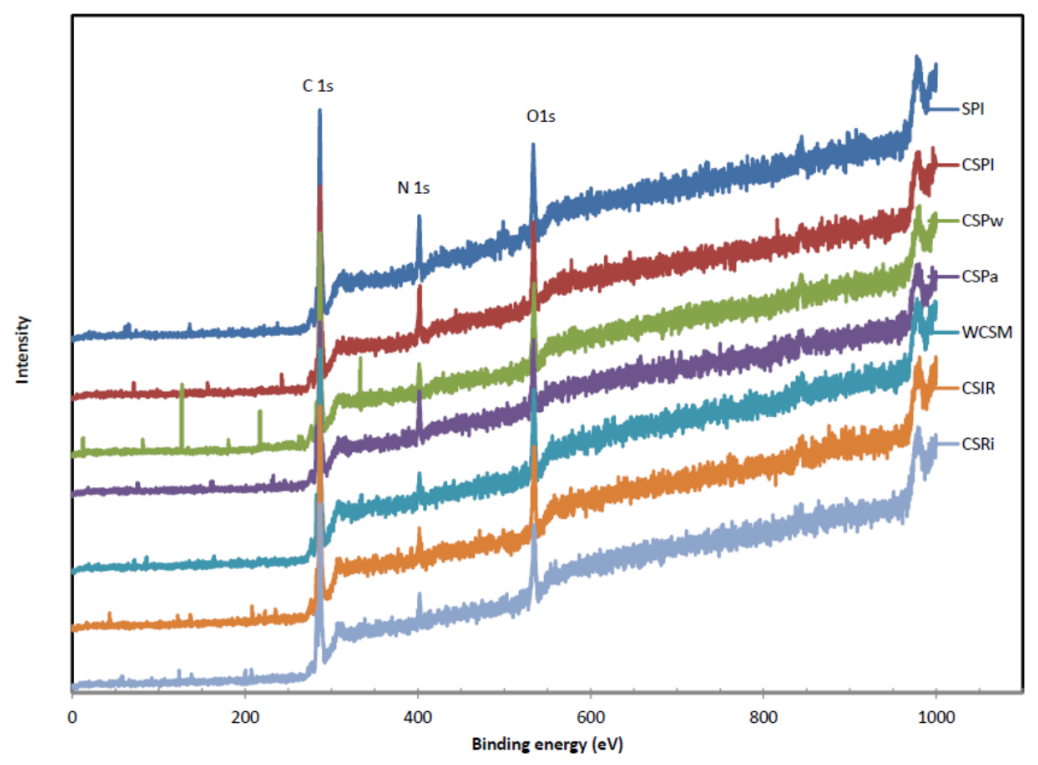

Figure 5. XPS survey spectra of the cottonseed meal products and soy protein samples. Refer to the legend of Fig. 1 for sample information 
Table 4. Characteristics and assignment of XPS peak components.

\begin{tabular}{|c|c|c|c|c|}
\hline & \multicolumn{4}{|c|}{$\mathrm{C} 1 \mathrm{~s}$ peak $(\mathrm{eV})$ and functional group assignment ${ }^{\mathrm{a}}$} \\
\hline & $\mathrm{C}(1), 284.8$ & $\mathrm{C}(2), 286.3$ & $\mathrm{C}(3), 287.9$ & $\mathrm{C}(4), 289.0$ \\
\hline & $\mathrm{C}-\mathrm{C}$ & $\mathrm{C}-(\mathrm{O}, \mathrm{N})$ & $\mathrm{O}-\mathrm{C}-\mathrm{O}, \mathrm{N}=\mathrm{C}-\mathrm{O}$ & $\mathrm{O}=\mathrm{C}-\mathrm{OH}$ \\
\hline & $\mathrm{C}-\mathrm{H}$ & Amide, amine & Acetal; amide & $\mathrm{O}=\mathrm{C}-\mathrm{OR}$ \\
\hline & Hydrocarbon & & & Carboxyl, ester \\
\hline $\mathrm{CSPw}^{\mathrm{b}}$ & 89.4 & 0.9 & 9.9 & 0.0 \\
\hline $\mathrm{CSPa}$ & 88.5 & 1.8 & 9.8 & 0.0 \\
\hline CSPI & 88.7 & 1.8 & 9.5 & 0.0 \\
\hline SPI & 94.9 & 2.8 & 2.4 & 0.0 \\
\hline WCSM & 95.9 & $0.0^{\mathrm{c}}$ & 3.5 & 0.6 \\
\hline CSIR & 93.4 & 0.0 & 6.3 & 0.3 \\
\hline CSRi & 95.3 & 0.0 & 4.8 & 0.1 \\
\hline
\end{tabular}

a Based the assignments in literature (Ahimou et al., 2007; Liu et al., 2014; Yang et al., 2016). The eV value of a specific peak of each sample changed slightly for best fitting.

b. CSPw and CSPa, sequentially extracted water-soluble protein fraction and alkali-soluble protein fraction, respectively; CSPI, one-step alkali-extracted cottonseed protein isolate; CSIR, the residual fraction after the twostep sequential extraction by water and alkali; CSRi, the residual fraction after one-step alkali extraction; WCSM, water-washed cottonseed meal; and SPI, soy protein isolate.

c. No peak detected.

Quantitative analysis of the four $\mathrm{C}$ species indicated that the $\mathrm{C}-\mathrm{C}$ aliphatic bond components [C (1) peak] dominated the surface of all seven samples (Table 4). Even though, the apparent difference in the C-C aliphatic components was observed in the protein samples and the carbohydrate residual samples after protein extraction. Similarly, $\mathrm{N}$-associated $\mathrm{C}$ functional groups $[\mathrm{C}(2)$ peak] found only with the four protein samples; O-associated carboxyl and ester $\mathrm{C}$ functional groups found only with the residual samples. These results were consistent with the total C, N, O peak abundances detected by the XPS analysis (Table 3). The predominant C-C functional group in these samples (especially the protein samples) implied that the $\mathrm{N}$-associated functional groups were underrepresented on the surface, and might also be attributed, in part, to the undetected $\mathrm{N}$ peak by SEM-EDS (Figure 2). XPS analysis was used to determine the elemental composition of the outermost $45 \AA$ of the surface layer (6 $\mathrm{nm}$ depth). For SEM-EDS with an accelerating voltage of $10 \mathrm{kV}$, the electron beam can penetrate to a thickness about $200 \mathrm{~nm}$ (Miculescu et al., 2011). Soy protein sample SPI showed the distribution pattern of the surface composition which was the same as that of the cottonseed protein samples. However, the specific values of the three $\mathrm{C}$ functional groups were obviously different from those of cottonseed proteins, which apparently led to the different morphology observed in Figure 1. Furthermore, the data of the surface C functional groups showed greater similarity between CSPI and CSPa than between CSPw and CSPI. Therefore, CSPa could be used in explanation of the similarity and difference of intrinsic fluorescence of the three protein samples observed previously (He et al., 2014c). The deconvulation data also demonstrated again that the surface composition of WCSM had greater similarity to that of residual sample CSIR and CSRi than that of cottonseed protein samples $\mathrm{CSP} w, \mathrm{CSPa}$, and CSPI. 

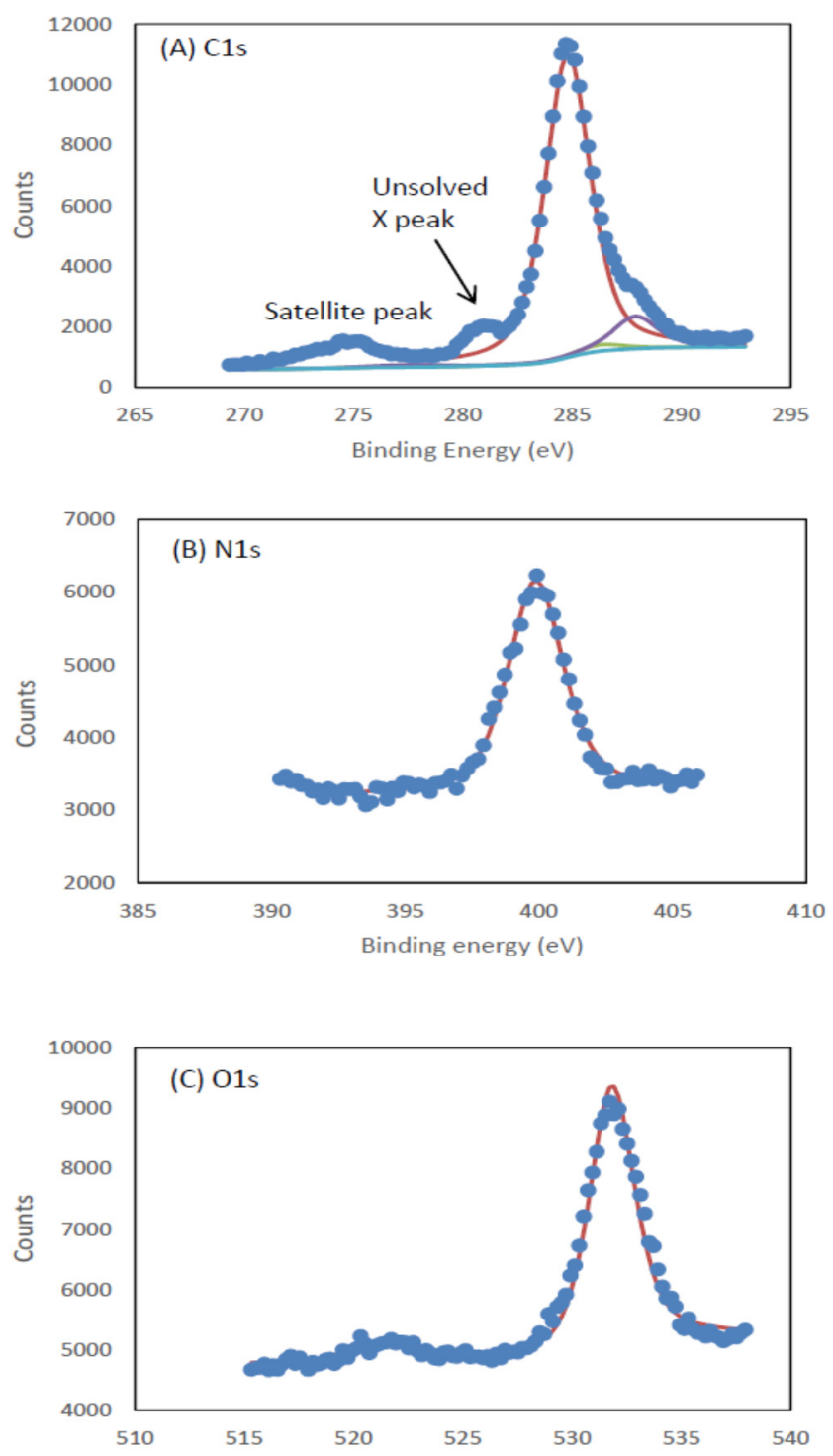

Figure 6. XPS spectra of the $\mathrm{C}, \mathrm{N}$, and $\mathrm{O}$ peaks of cottonseed protein isolate (CSPI) and their deconvolution curves

\section{Conclusion}

Multiple instrumental techniques revealed the morphology and surface composition of six cottonseed meal products which differed from a commercial soy protein product. One-step total cottonseed protein isolate and twostep sequentially extracted water and alkali soluble cottonseed fractions all showed compact crystalline structures while the residues after protein extraction either by one-step or two-step procedures showed more loose and porous structures. The surface composition of the protein samples were $\mathrm{N}$-associated but under-represented. The surface composition of the residues was characterized by the hydrocarbon (polysaccharides) features, distinct from the proteins. Although it contained both insoluble protein and polysaccharide components, the water-washed cottonseed meal demonstrated its surface features more similar to the polysaccharide-predominant residual samples than to the protein samples.

\section{Acknowledgments}

We thank Tanya Goehring (Tulane University, School of Science and Engineering) for XRD analysis. Mention of trade names or commercial products in this publication is solely for the purpose of providing specific information and does not imply recommendation or endorsement by the U.S. Department of Agriculture. USDA is an equal opportunity provider and employer. 


\section{References}

Adhikari, B. B., Appadu, P., Chae, M., and Bressler, D.C. (2017). Protein-based wood adhesives: current trends of preparation and application, In Z. He (Ed.), Bio-based Wood Adhesives: Preparation, Characterization, and Testing (pp. 1-58). CRC Press, Boca Raton, FL.

Ahimou, F., Boonaert, C. J. P., Adriaensen, Y., Jacques, P., Thonart, P., Paquot, M., \& Rouxhet, P. G. (2007). XPS analysis of chemical functions at the surface of Bacillus subtilis. J. Colloid Interf. Sci., 309, 49-55.

Bellaloui, N., Turley, R. B., \& Stetina, S. R. (2015). Water stress and foliar boron application altered cell wall boron and seed nutrition in near-isogenic cotton lines expressing fuzzy and fuzzless seed phenotypes. PloS one, 10, e0130759. https://doi.org/0130710.0131371/journal.pone.0130759

Berardi, L., \& Cherry, J. (1979). Preparation and composition of coprecipitated protein isolates from cottonseed, soybean, and peanut flours. Cereal Chem., 56, 95-100.

Chen, J., Chen, X., Zhu, Q., Chen, F., Zhao, X., \& Ao, Q. (2013). Determination of the domain structure of the 7S and 11S globulins from soy proteins by XRD and FTIR. J. Sci. Food Agric., 93, 1687-1691. https://doi.org/10.1002/jsfa.5950.

Cheng, H. N., Dowd, M.K., \& He, Z. (2013). Investigation of modified cottonseed protein adhesives for wood composites. Ind. Crop. Prod., 46, 399-403. https://doi.org/10.1016/j.indcrop.2013.02.021.

Cheng, H. N., Ford, C. V., Dowd, M. K., \& He. Z. 2016. Use of additives to enhance the properties of cottonseed protein as wood adhesives. Int. J. Adhes. Adhes., 68, 156-160. http://dx.doi.org/10.1016/j.ijadhadh.2016. 02.012 .

Gaiani, C., Mullet, M., Arab-Tehrany, E., Jacquot, M., Perroud, C., Renard, A., \& Scher, J. (2011). Milk proteins differentiation and competitive adsorption during spray-drying. Food hydrocoll., 25, 983-990. https://doi.org/10.1016/j.foodhyd.2010.09.013.

Gazulla, M., Rodrigo, M., Blasco, E., \& Orduna, M. (2013). Nitrogen determination by SEM-EDS and elemental analysis. X-Ray Spectrometry, 42, 394-401. https://doi.org/10.1002/xrs.2490

Grevellec, J., Marquie, C., Ferry, L., Crespy, A., \& Vialettes, V. (2001). Processability of cottonseed proteins into biodegradable materials. Biomacromolecules, 2, 1104-1109.

Grewal, J., \& Khare, S. (2017). 2-Pyrrolidone synthesis from $\gamma$-aminobutyric acid produced by Lactobacillus brevis under solid-state fermentation utilizing toxic deoiled cottonseed cake. Bioprocess Biosyst. Eng., 40, 145-152. https://doi.org/10.1007/s00449-016-1683-9

Han, Y. W. (1988). Removal of phytic acid from soybean and cottonseed meals. J. Agric. Food Chem., 36, 11811183.

He, Z., \& Cheng, H. N. (2017). Preparation and utilization of water washed cottonseed meal as wood adhesives, In: He, Z. (Ed.) Bio-based Wood Adhesives: Preparation, Characterization, and Testing (pp. 156-178). CRC Press, Boca Raton, FL.

He, Z., \& Chiozza, F. (2017). Adhesive strength of pilot-scale-produced water-washed cottonseed meal in comparison with a synthetic glue for non-structural interior application. J. Mater. Sci. Res., 6(3), 20-26. https://doi.org/10.5539/jmsr.v6n3p20.

He, Z., Cao, H., Cheng, H. N., Zou, H., \& Hunt, J. F. (2013a). Effects of vigorous blending on yield and quality of protein isolates extracted from cottonseed and soy flours. Modern Appl. Sci., 7(10), 79-88. https://doi.org/ 10.5539/mas.v7n10p79

He, Z., Chapital, D. C., \& Cheng, H. N. (2016b). Effects of pH and storage time on the adhesive and rheological properties of cottonseed meal-based products. J. Appl. Polymer Sci., 133, 43637. https://doi.org/43610.41002/ APP. 43637

He, Z., Chapital, D. C., Cheng, H. N., Klasson, K. T., Olanya, O. M., \& Uknalis, J. (2014a). Application of tung oil to improve adhesion strength and water resistance of cottonseed meal and protein adhesives on maple veneer. Ind. Crop. Prod., 61, 398-402. https://doi.org/10.1016/j.indcrop.2014.07.031

He, Z., Chapital, D.C., \& Cheng, H. N. (2016a). Comparison of the adhesive performances of soy meal, water washed meal fractions, and protein isolates. Modern Appl. Sci., 10(5), 112-120. https://doi.org/10.5539/ mas.v10n5p112. 
He, Z., Cheng, H. N., Chapital, D. C., \& Dowd, M. K. (2014b). Sequential fractionation of cottonseed meal to improve its wood adhesive properties. J. Am. Oil Chem. Soc., 91, 151-158. https://doi.org/10.1007/s11746013-2349-2.

He, Z., Cheng, H. N., Klasson, K. T., Olanya, O. M., \& Uknalis, J. (2017b). Effects of particle size on the morphology and water- and thermo-resistance of washed cottonseed meal-based wood adhesives. Polymers, 9, 675. http://dx.doi.org/10.3390/polym9120675.

He, Z., Honeycutt, C. W., Zhang, T., \& Bertsch, P. M. (2006). Preparation and FT-IR characterization of metal phytate compounds. J. Environ. Qual., 35, 1319-1328.

He, Z., Klasson, K. T., Wang, D., Li, N., Zhang, H., Zhang, D., \& Wedegaertner, T. C. (2016c). Pilot-scale production of washed cottonseed meal and co-products. Modern Appl. Sci., 10(2), 25-33. https://doi.org/10. 5539/mas.v10n2p25.

He, Z., Uchimiya, M., \& Cao, H. (2014c). Intrinsic fluorescence excitation-emission matrix spectral features of cottonseed protein fractions and the effects of denaturants. J. Am. Oil Chem. Soc., 91, 1489-1497. https://doi.org/10.1007/s11746-014-2495-1.

He, Z., Uchimiya, S. M., \& Guo, M. (2016d). Production and characterization of biochar from agricultural byproducts: Overview and use of cotton biomass residues, In M. Guo, Z. He, S. M. Uchimiya (Eds.), Agricultural and Environmental Applications of Biochar: Advances and Barriers (pp. 63-86). Soil Science Society of America, Inc., Madison, WI. https://doi.org/10.2136/sssaspecpub63.2014.0037.5

He, Z., Zhang, H., \& Olk, D. C. (2015). Chemical composition of defatted cottonseed and soy meal products. PLoS One, 10(6), e0129933. https://doi.org/0129910.0121371/journal.pone.0129933

He, Z., Zhang, H., Tewolde, H., \& Shankle, M. (2017b). Chemical characterization of cotton plant parts for multiple uses. Agric. Environ. Lett., 2, 110044. https://doi.org/110010.112134/ael112016.110011.110044

He, Z., Zhong, J., \& Cheng, H. N. (2013b). Conformational change of metal phytates: solid state $1 \mathrm{D}{ }^{13} \mathrm{C}$ and $2 \mathrm{D}$ ${ }^{1} \mathrm{H}^{13} \mathrm{C}$ NMR spectroscopic investigations. J. Food Agri. Environ., 11(1), 965-970.

Hou, D., Lin, D., Zhao, C., Wang, J., \& Fu, C. (2017). Control of protein (BSA) fouling by ultrasonic irradiation during membrane distillation process. Sep. Purif. Technol., 175, 287-297. https://doi.org/10.1016/j.seppur. 2016.11.047.

Jia, J., Gao, X., Hao, M., \& Tang, L. (2017). Comparison of binding interaction between $\beta$-lactoglobulin and three common polyphenols using multi-spectroscopy and modeling methods. Food Chem., 228, 143-151. https://doi.org/10.1016/j.foodchem.2017.01.131

Kelly, G. M., O’Mahony, J.A., Kelly, A. L., Huppertz, T., Kennedy, D., \& O’Callaghan, D. J. (2015). Influence of protein concentration on surface composition and physico-chemical of spray-dried milk protein concentrate powders. Inter. Dairy J., 51, 34-40. https://doi.org/10.1016/j.idairyj.2015.07.001

King, E. E. (1980). Compositional relationships among electrophoretic isolates from cottonseed protein bodies. Phytochem., 19, 1647-1651.

Liu, F., Wang, X., Zhao, X., Hu, H., Chen, F., \& Sun, Y. (2014). Surface properties of walnut protein from AOT reverse micelles. Int. J. Food Sci. Technol., 49, 626-633. https://doi.org/10.1111/ijfs.12345

Liu, Y., Campbell, B. T., Delhom, C., \& Martin, V. (2015). Comparative relationship of fiber strength and yarn tenacity in four cotton cultivars. J. Mater. Sci. Res., 5(1), 46-53. https://doi.org/10.5539/jmsr.v5n1p46

Liu, Y., He, Z., Shankle, M., \& Tewolde, H. (2016). Compositional features of cotton plant biomass fractions characterized by attenuated total reflection Fourier transform infrared spectroscopy. Ind. Crop. Prod., 79, 283-286. https://doi.org/10.1016/j.indcrop.2015.11.022

Luna-Valdez, J. G., Balandran-Quintana, R. R., Azamar-Barrios, J. A., Ramos Clamont-Montfort, G., MendozaWilson, A. M., Mercado-Ruiz, J. N., ... Chaquilla-Quilca, G. (2017). Structural and physicochemical characterization of nanoparticles synthesized from an aqueous extract of wheat bran by a cold-set gelation/desolvation approach. Food Hydrocolloids, 62, 165-173. https://doi.org/10.1016/j.foodhyd.2016. 07.034

Luo, J., Luo, J., Li, X., Li, K., Gao, Q., \& Li, J. (2016). Toughening improvement to a soybean meal-based bioadhesive using an interpenetrating acrylic emulsion network. J. Mater. Sci., 51, 9330-9341. https://doi.org/10.1007/s10853-016-0180-5 
Miculescu, F., Jepu, I., Porosnicu, C., Lungu, C., Miculescu, M., \& Burhala, B. (2011). A study on the influence of the primary electronbeam on nanodimensional layers analysis. Digest J. Nanomater. Biostruc., 6, 307-317.

Muruganantham, S., Anbalagan, G., \& Ramamurthy, N. (2009). FT-IR and SEM-EDS comparative analysis of medicinal plants, Eclipta alba Hassk and Eclipta prostrata Linn. Romanian J. Biophys, 19, 285-294.

Nawaz, M. A., Gaiani, C., Fukai, S., \& Bhandari, B. (2016). X-ray photoelectron spectroscopic analysis of rice kernels and flours: Measurement of surface chemical composition. Food Chem., 212, 349-357. https://doi.org/10.1016/j.foodchem.2016.05.188.

Olivares, O., Likhanova, N., Gomez, B., Navarrete, J., Llanos-Serrano, M., Arce, E., \& Hallen, J. (2006). Electrochemical and XPS studies of decylamides of $\alpha$-amino acids adsorption on carbon steel in acidic environment. Appl. Surf. Sci., 252, 2894-2909.

Proto, M., Supino, S., \& Malandrino, O. (2000). Cotton: a flow cycle to exploit. Ind. Crop. Prod., 11, 173-178.

Qi, G., Li, N., Sun, X. S., \& Wang, D. (2017). Adhesion properties of soy protein subunits and protein adhesive modification, In Z. He (Ed.), Bio-based Wood Adhesives: Preparation, Characterization, and Testing (pp. 59-85). CRC Press, Boca Raton, FL.

Saad, M. M., Gaiani, C., Mullet, M., Scher, J., \& Cuq, B. (2011). X-ray photoelectron spectroscopy for wheat powders: Measurement of surface chemical composition. J. Agr. Food Chem., 59, 1527-1540.

Swiatkiewicz, S., Arczewska-Wlosek, A., \& Jozefia, D. (2016). The use of cottonseed meal as a protein source for poultry: an updated review. World Poultry Sci. J., 72, 473-484. https://doi.org/10.1017/S0043933916000258

Tazisong, I. A., He, Z., \& Senwo, Z. N. (2013). Inorganic and enzymatically hydrolyzable organic phosphorus of Alabama Decatur silt loam soils cropped with upland cotton. Soil Sci., 178, 231-239. https://doi.org/10.1097/ SS.0b013e31829cf464

Tewolde, H., Shankle, M. W., Way, T. R., Adeli, A., Brooks, J. P., \& He, Z. (2015). Enhancing management of fall-applied poultry litter with cover crop and subsurface band placement in no-till cotton. Agron. J., 107, 449-458. https://doi.org/10.2134/agronj14.0266

Tserki, V., Matzinos, P., Kokkou, S., \& Panayiotou, C. (2005). Novel biodegradable composites based on treated lignocellulosic waste flour as filler. Part I. Surface chemical modification and characterization of waste flour. Composites Part A, 36, 965-974. https://doi.org/10.1016/j.compositesa.2004.11.010

Tunc, S., \& Duman, O. (2007). Thermodynamic properties and moisture adsorption isotherms of cottonseed protein isolate and different forms of cottonseed samples. J. Food Engineer., 81, 133-143. https://doi.org/10.1016/j.jfoodeng.2006.10.015

Windeatt, J. H., Ross, A. B., Williams, P. T., Forster, P. M., Nahil, M. A., \& Singh, S. (2014). Characteristics of biochars from crop residues: Potential for carbon sequestration and soil amendment. J. Environ. Manag., 146, 189-197. https://doi.org/10.1016/j.jenvman.2014.08.003

Yang, Y., Wikiel,, A. J., Dall'Agnol, L. T., Eloy, P., Genet, M. J., Moura, J. J., Sand, W., Dupont-Gillain, C. C., \& Rouxhet, P. G. (2016). Proteins dominate in the surface layers formed on materials exposed to extracellular polymeric substances from bacterial cultures. Biofouling, 32, 95-108. https://doi.org/10.1080/08927014. 2015.1114609.

Zhang, B., Cui, Y., Yin, G., Li, X., \& Zhou, X. (2009). Alkaline extraction method of cottonseed protein isolate. Modern Appl. Sci., 3(3), 77-82.

Zhang, J., Wang, Y., Zhang, L., Zhang, R., Liu, G., \& Cheng, G. (2014). Understanding changes in cellulose crystalline structure of lignocellulosic biomass during ionic liquid pretreatment by XRD. Bioresour. Technol., 151, 402-405. https://doi.org/10.1016/j.biortech.2013.10.009

Zhao, X. Y., Chen, J., Zhu, Q. J., Du, F. L., Ao, Q., \& Liu, J. (2011). Surface characterization of 7S and 11S globulin powders from soy protein examined by X-ray photoelectron spectroscopy and scanning electron microscopy. Colloids Surfaces B., 86, 260-268. https://doi.org/10.1016/j.colsurfb.2011.03.044

Zhao, X., Zhu, H., Zhang, B., Chen, J., Ao, Q., \& Wang, X. (2015). XRD, SEM, and XPS analysis of soybean protein powders obtained through extraction involving reverse micelles. J. Am. Oil Chem. Soc., 92, 975-983. https://doi.org/10.1007/s11746-015-2657-9 
Zhou, J.-Z., Zhang, H., Gao, L., Wang, L., \& Qian, H.-F. (2015). Influence of pH and ionic strength on heatinduced formation and rheological properties of cottonseed protein gels. Food Bioprod. Process., 96, $27-34$. https://doi.org/10.1016/j.fbp.2015.06.004

Zhu, X., Wang, D., \& Sun, X. S. (2016). Physico-chemical properties of camelina protein altered by sodium bisulfite and guanidine-HCl. Ind. Crop. Prod., 83, 453-461. https://doi.org/10.1016/j.indcrop.2015.12.085

\section{Copyrights}

Copyright for this article is retained by the author(s), with first publication rights granted to the journal.

This is an open-access article distributed under the terms and conditions of the Creative Commons Attribution license (http://creativecommons.org/licenses/by/4.0/). 